\title{
PENGARUH KOMPOS ASAL KULIT JENGKOL (Phitecolobium jiringa (J ack) Prain ex King) TERHADAP CIRI KIMIA TANAH SAWAH DAN PRODUKSI TANAMAN PADI
}

\author{
Gusnidar,Yulnafatmawita, dan Rosa Nofianti \\ J urusan Tanah F akultas Pertanian U niversitass Andalas Padang \\ eni_tanah@yahoo.co.id
}

\begin{abstract}
This research had been conducted in the greenhouse and the Soil Laboratory of the Faculty of Agriculture, Andalas University, Padang, West Sumatera. The study was done from March until October 2011. The aims of this research were to get the effect of compost from jengkol shell on chemical properties of paddy soil and rice yield. The experiments were conducted in a greenhouse and the experimental units were arranged based on completely randomized design (CRD). The treatments were application of compost $\mathrm{K}_{0}=0$ tons $/ \mathrm{ha}(0 \mathrm{~g} / \mathrm{pot}), \mathrm{K}_{1}=5$ tons/ha (20 $\mathrm{g} / \mathrm{pot}), \mathrm{K}_{2}=10$ tons/ha $(40 \mathrm{~g} / \mathrm{pot}), \mathrm{K}_{3}=20$ tons/ha $(80 \mathrm{~g} / \mathrm{pot}), \mathrm{K}_{4}=40$ tons/ha $(160 \mathrm{~g} / \mathrm{pot})$. The data were compared to the criteria of soil chemical properties and plant data were statistically analysed for the variance. If the F calculated $>\mathrm{F}$ table, the analyses were continued by using DNMRT at 0.05 level of significance. The results showed that application of $160 \mathrm{~g}$ compost/pot increased soil $\mathrm{pH}$ by $21.78 \%$, N-total by $123.07 \%$, organic-C by $65.84 \%$, available $\mathrm{P}$ by $93.55 \%$, $\mathrm{K}_{\text {exch. }}$ by $238.35 \%, \mathrm{Ca}$ exch. by $133.33 \%, \mathrm{Mg}_{\text {exch. }}$ by $90.00 \%$, CEC by $238.90 \%, \mathrm{Cu}_{\text {exch. }}$ by $54,10 \%$, as well as the yield by $12,68 \%$ compared to the treatment without compost application.
\end{abstract}

Keywords : jengkol, nutrients, paddy soil, production

\section{PENDAHULUAN}

Kompos asal limbah kulit jengkol diasumsikan bernilai tinggi, karena menurut Pitojo (1995) kulit jengkol tersebut mengandung minyak atsiri, saponin, alkaloid, terpenoid, steroid, tanin, glikosida, protein, karbohidrat, kalsium (Ca), fospor (P) serta vitamin. Enni dan Krispinus (1998) melakukan penelitian skala laboratorium, melaporkan bahwa kulit buah jengkol yang didekomposisikan dalam tanah sawah membentuk alkaloid, terpenoid, steroid dan asam lemak rantai panjang serta asam fenolat. Selanjutnya Enni (2003) menguji kulit jengkol sebagai herbisida alami pada tanaman padi sawah di Semarang. Pada sawah tersebut ditebar kulit jengkol segar yang telah diiris melintang setebal $1 \mathrm{~cm}$ dengan dosis $1 \mathrm{~kg}$ permeter persegi (setara 10 ton kulit jengkol segar per hektar). Dari hasil penelitian tersebut, ternyata mulsa kulit jengkol dapat menekan pertumbuhan gulma tanpa menganggu pertumbuhan tanaman padi, dan diduga dapat menambah unsur hara pada tanah sawah.

Delsi (2010), meneliti pengaruh ekstrak kulit jengkol terhadap viabilitas dan vigor gulma pada tanaman yang sama. Dari laporannya diketahui bahwa pada konsentrasi $10 \%$ ekstrak kulit jengkol meningkatkan pertumbuhan tanaman padi, dan menurunkan viabilitas serta vigor gulma. Dari hasil analisis pendahuluan ternyata kulit mengandung hara; $1,82 \% \mathrm{~N} ; 0,03 \% \mathrm{P} ; 2,10 \%$ $\mathrm{K} ; 0,27 \% \mathrm{Ca} ; 0,25 \% \mathrm{Mg}$. Berdasarkan penelitian penggunaan kulit jengkol sebagai herbisida dan kemampuannya menghambat viabilitas gulma, serta berdasarkan analisis kandungan hara sebelum penelitian, maka diasumsikan kulit jengkol sangat baik dijadikan kompos sebagai sumber hara dan sekaligus dapat menekan pertumbuhan gulma. Akan tetapi pengaruhnya terhadap ciri kimia tanah sawah dan produksi tanaman padi jika limbah kulit jengkol diolah menjadi kompos belum diketahui, sehingga perlu dipelajari melalui penelitian. Tujuannya adalah untuk mempelajari pemberian kompos asal kulit jengkol terhadap ciri kimia tanah sawah dan 
pengaruhnya terhadap produksi tanaman padi. Penelitian ini diharapkan mampu meningkatkan nilai limbah kulit jengkol, dan menemukan bahan kompos yang dapat meningkatkan ketersediaan hara tanah sawah dan produksi padi, sekaligus bisa menekan gulma. Dengan demikian limbah ini dapat dikembangkan menjadi pupuk organik yang baik pada lahan sawah yang dikelola secara SRI.

\section{METODE PENELITIAN}

Penelitian berlangsung selama 7 bulan di rumah kaca dan laboratorium Tanah Fakultas Pertanian Universitas Andalas Padang pada tahun 2011. Tanah sawah (asal Ultisol) diambil dari lahan sawah percobaan Fakultas Pertanian Unand, Limau Manis Padang. Tanah ini sejak tahun 1992 tidak selalu disawahkan, sering digunakan untuk tanaman hortikultura dan juga sering diberakan. Bahan kompos asal kulit jengkol segar, pupuk buatan Urea, SP-36, KCl serta benih padi varietas IR 42 .

Percobaan dalam Rancangan Acak Lengkap (RAL) dengan 5 perlakuan dan 3 ulangan. Data penelitian dianalisis ragam, bila menunjukkan hasil yang berbeda nyata, dilakukan uji lanjut Duncan's New Multiple Rang Tes (DNMRT) pada taraf nyata 5\%. Perlakuannya adalah ;

$\mathrm{K} 0=0$ ton kompos/ha ( $0 \mathrm{~g}$ kompos/pot $)$, $\mathrm{K} 1=5$ ton kompos/ha (20 g kompos/pot), $\mathrm{K} 2=10$ ton kompos/ha (40 g kompos/pot), $\mathrm{K} 3=20$ ton kompos/ha (80 g kompos/pot), $\mathrm{K} 4=40$ ton kompos/ha (160 g kompos/pot).

Penelitian dimulai dari pengomposan kulit jengkol dan dianalisis kadar hara $\mathrm{N}, \mathrm{P}$, $\mathrm{K}, \mathrm{Ca}, \mathrm{Mg}, \mathrm{C}$-organik kompos dan $\mathrm{C} / \mathrm{N}$. Tanah diambil pada kedalaman $0-20 \mathrm{~cm}$, secara komposit, selanjutnya dikering anginkan, dihaluskan, diayak dengan ayakan $2 \mathrm{~mm}$ dan diaduk rata. Tanah tersebut dimasukan ke dalam pot, masing-masingnya sebanyak $8 \mathrm{~kg}$ (setara dengan kering mutlak). Untuk analisis kimia tanah awal diambil sebanyak 100 g. Sebelum ditanami tanah terlebih dahulu diaduk dengan kompos sesuai perlakuan sampai tercampur sempurna, kemudian dilakukan pelumpuran tanah.
Setelah itu diinkubasi selama 2 minggu dalam kondisi kapasitas lapang. Setelah masa inkubasi diambil sampel tanah masingmasing pot percobaan lebih kurang $100 \mathrm{~g}$ untuk analisis beberapa cirri kimia tanah, lalu dikering anginkan dan diayak dengan ayakan $0,5 \mathrm{~mm}$. Selanjutnya dilakukan persiapan bibit, penanaman, pemupukan, pemeliharaan dan panen.

Untuk pengamatan ciri kimia dari kompos kulit jengkol, maka dilakukan analisis hara nitrogen $(\mathrm{N})$, fosfor $(\mathrm{P})$, kalium $(\mathrm{K})$, kalsium $(\mathrm{Ca})$, magnesium $(\mathrm{Mg}), \mathrm{C}$ organik dan ratio $\mathrm{C} / \mathrm{N}$. Pengamatan terhadap tanah tanah awal dan sesudah inkubasi meliputi: $\mathrm{pH}$ tanah $\mathrm{H}_{2} \mathrm{O}$ 1:1, metoda Elektrometrik, C-organik metoda Walkley dan Black, N-total metoda Kjeldhal, Ptersedia metoda Bray II, $\mathrm{K}, \mathrm{Ca}$, dan $\mathrm{Mg}$ metoda Amonium asetat pH $71 \mathrm{~N}$, tembaga $(\mathrm{Cu})$, dengan metoda Pencucian, kapasitas tukar kation (KTK) metoda Amonium asetat $1 \mathrm{~N}$ pH 7, dan $\mathrm{C} / \mathrm{N}$. Pengamatan terhadap tanaman meliputi; tinggi tanaman, jumlah anakan total, jumlah anakan produktif, bobot kering jerami, bobot kering gabah dan bobot 1000 biji serta analisis serapan hara N, P, K tanaman.

\section{HASIL DAN PEMBAHASAN}

Ciri kimia tanah yang digunakan untuk penelitian

Tanah penelitian berasal dari ordo Ultisol dengan ciri kimia seperti yang tertera pada Tabel 1. Nilai $\mathrm{pH}$ agak masam, sedangkan N-total, KTK, dan Cu-dd berada pada kriteria rendah, $\mathrm{C}$-organik sedang serta ratio $\mathrm{C} / \mathrm{N}$ dan $\mathrm{K}$-dd terdapat pada kriteria tinggi, kadar Ca-dd, dan $\mathrm{Mg}$-dd sangat rendah, serta P-tersedia dalam kriteria sedang. Ciri kimia tanah seperti pada Tabel 2, jelas tidak seimbang bagi pertumbuhan tanaman seperti unsur makro K-dd tinggi, sementara $\mathrm{N}$, KTK, dan $\mathrm{Cu}$-dd rendah, Ca-dd dan $\mathrm{Mg}$ dd sangat rendah. Diharapkan dengan pemberian kompos kulit jengkol dapat memperbaiki sifat kimia tanah tersebut. Menurut Hardjowigeno (1995), tanah dengan 
Tabel 1. Ciri kimia tanah yang digunakan dalam penelitian

\begin{tabular}{|c|c|c|}
\hline Jenis analisis & Nilai & Kriteria \\
\hline $\mathrm{pH} \mathrm{H} \mathrm{H}_{2} \mathrm{O}(1: 1)$ & 5,60 & Agak masam * \\
\hline N-total $\quad(\%)$ & 0,13 & Rendah * \\
\hline C-Organik (\%) & 2,84 & Sedang $*$ \\
\hline Ratio C/N & 21,84 & Tinggi $* *$ \\
\hline P-tersedia (ppm) & 39,11 & Sedang $*$ \\
\hline Ca-dd (me/100 g) & 0,36 & Sangat rendah * \\
\hline Mg-dd (me/100 g) & 0,60 & Sangat rendah * \\
\hline K-dd $\quad(\mathrm{me} / 100 \mathrm{~g})$ & 0,73 & Tinggi $*$ \\
\hline KTK $\quad(\mathrm{me} / 100 \mathrm{~g})$ & 11,54 & Rendah * \\
\hline Cu-dd (ppm) & 18,15 & Rendah *** \\
\hline
\end{tabular}

*) : Staf Pusat penelitian tanah (1983; cit Hardjowigeno, 2003)

**) : Team 4 Architects and Consulting Engineer bekerjasama dengan Fakultas Pertanian Universitas Andalas (1981)

***) : Rosmarkan, dan Yuwono (2002)

$\underline{\text { Tabel 2. Kandungan hara kulit jengkol sebelum dan sesudah dikomposkan selama } 2 \text { bulan }}$

\begin{tabular}{cccc}
\hline \multicolumn{2}{c}{ Parameter pengamatan } & Sebelum dikomposkan & Sesudah dikomposkan \\
\hline Kadar Air (\%) & & 65,56 & 97,62 \\
Kadar hara : & & \\
N-total & $(\%)$ & 1,82 & 1,18 \\
P-total & $(\%)$ & 0,32 & 0,65 \\
K-total & $(\%)$ & 2,10 & 7,24 \\
Ca-total & $(\%)$ & 0,27 & 1,95 \\
Mg-total & $(\%)$ & 0,25 & 2,52 \\
C-total & $(\%)$ & 44,02 & 29,16 \\
C/N & & 24,19 & 24,71 \\
\hline
\end{tabular}

KTK rendah kemampuan menyerap dan menyediakan unsur haranya juga rendah, karena unsur-unsur hara tersebut tidak terdapat dalam kompleks jerapan koloid maka unsur-unsur hara tersebut mudah hilang dan tercuci.

\section{Ciri Kimia Kompos Kulit Jengkol}

Hasil analisis beberapa hara kulit jengkol sebelum dan sesudah dikomposkan selama 2 bulan disajikan pada Tabel 2 .
Kadar hara yang terdapat pada Tabel 2, bervariasi. Kadar hara P meningkat sebesar $0,33 \%$ dan $\mathrm{K}$ sebesar 5,14\%, Mg meningkat sebesar 2,27\%, Ca-total meningkat sebesar $1,68 \%$ pada bahan yang telah dikomposkan, sedangkan $\mathrm{N}$ mengalami penurunan sebesar 0,64\%. Demikian juga C-total menurun sebesar $14,52 \%$, nilai $\mathrm{C} / \mathrm{N}$ dari 24,19 sebelum dikompos menjadi 24,71 sesudah dikompos. Meningkatnya kadar $\mathrm{P}, \mathrm{K}, \mathrm{Ca}$, dan $\mathrm{Mg}$ kompos hasil dekomposisi kulit jengkol adalah akibat di starter dengan pupuk 
kandang (pukan) dan Stardec. Nilai C/N kompos kulit jengkol sedikit lebih tinggi dari pada yang belum dikomposkan hal ini disebabkan sewaktu pengamatan kompos belum melapuk sempurna. Hal ini dicirikan oleh kadar hara pada kompos kulit jengkol terutama $\mathrm{N}$ dan $\mathrm{C}$ yang mengalami penurunan, sehingga mengakibatkan nilai $\mathrm{C} / \mathrm{N}$ nya lebih tinggi dari sebelum pengomposan sehingga ratio $\mathrm{C} / \mathrm{N}$ kompos yang diaplikasikan masih > 20. Menurut Hakim et al (1986), suatu dekomposisi bahan organik yang lanjut dicirikan oleh $\mathrm{C} / \mathrm{N}$ yang rendah, sedangkan $\mathrm{C} / \mathrm{N}$ yang tinggi menunjukkan dekomposisi belum lanjut atau baru mulai. Berarti dengan $\mathrm{C} / \mathrm{N}$ yang tinggi pada kompos kulit jengkol ini menandakan bahwa pengomposan belum lanjut atau baru dimulai, sehingga ketersediaan haranya belum maksimum. Hal ini tentu akan mempengaruhi pertumbuhan dan produksi tanaman yang ditanam.

Sifat Kimia Tanah Setelah Dinkubasi dengan Kompos Kulit Jengkol

Nilai $\mathrm{pH} \mathrm{H}_{2} \mathrm{O}$

Pemberian kompos kulit jengkol terhadap $\mathrm{pH} \quad \mathrm{H}_{2} \mathrm{O}$ (Tabel 3) cenderung meningkat. Pemberian kompos 160 g/pot merupakan peningkatan $\mathrm{pH}$ yang tertinggi mencapai 6,82 dalam kriteria netral dan terendah tanpa pemberian kompos yaitu sebesar 5,73 dalam kriteria agak masam. Peningkatan $\mathrm{pH}$ diasumsikan karena pengaruh asam-asam organik yang dihasilkan akibat proses dekomposisi bahan organik. Asam-asam organik tersebut akan berfungsi melepaskan unsur hara tanah menjadi lebih tertsedia, seperti Ca-dd, Mg-dd dan K-dd, akibatnya $\mathrm{pH}$ bertambah besar. Di samping itu, juga diakibatkan perubahan kondisi tanah dari kondisi oksidasi menjadi tereduksi. Menurut Rykson dan Sudadi (2001), meningkatnya $\mathrm{pH}$ tanah terjadi karena reaksi reduksi-oksidasi (redoks). Kenaikan $\mathrm{pH}$ juga dipengaruhi oleh peningkatan kation-kation seperti K-dd, Ca-dd, dan Mg-dd dalam tanah, seperti yang dikemukakan Hakim et al (1986) bahwa bertambahnya $\mathrm{K}, \mathrm{Ca}$, dan $\mathrm{Mg}$ dalam tanah akan meningkatkan $\mathrm{pH}$, karena basa- basa tersebut akan menukar $\mathrm{H}^{+}$dalam komplek jerapan.

Kadar C-organik, N-total dan Ratio C/N Tanah

Hasil pengukuran C-organik, N-total dan ratio $\mathrm{C} / \mathrm{N}$ tanah sesudah inkubasi (Tabel 3), secara umum terlihat bahwa meningkatnya takaran kompos yang diberikan juga berpengaruh terhadap peningkatan kandungan C-organik pada tanah sawah. Peningkatan takaran kompos yang diberikan cenderung menambah kandungan C-organik tanah. Nilai kandungan $\mathrm{C}$-organik yang tertinggi terdapat pada perlakuan pemberian kompos $160 \mathrm{~g} / \mathrm{pot}$ yaitu 4,71 \% tergolong tinggi, jika dibandingkan dengan tanpa diberi kompos hanya sebesar 2,84 \% (kriteria sedang).

Pemberian kompos asal kulit jengkol sebanyak 20-160 g/pot menambah ketersediaan C-organik tanah dari sedang menjadi tinggi. Peningkatan kandungan Corganik tanah tersebut sudah jelas sumbangan dari C-organik kompos. Pemberian kompos ke dalam tanah dapat meningkatkan aktifitas mikroorganisme tanah dalam merombak bahan organik tanah. Perombakan akan membebaskan unsur-unsur hara, sehingga dapat dimanfaatkan oleh tanaman. Pemberian bahan organik berupa kompos akan meningkatkan aktifitas mikroba dalam tanah, sehingga unsur hara lebih tersedia bagi tanaman. Setyamidjaja (1986); Gusnidar, 2007; Gusnidar, Yasin dan Burbey (2008) berpendapat bahwa pemberian bahan organik baik berupa kompos, pupuk hijau atau pengembalian jerami ke dalam tanah akan menambah ketersediaan unsur hara dan kandungan bahan organik tanah.

Pemberian kompos juga dapat meningkatkan kadar $\mathrm{N}$ tanah walaupun tidak terlalu tinggi. Nilai $\mathrm{N}$ tanah tertinggi terdapat pada perlakuan pemberian $80 \mathrm{~g} /$ pot, dan berada dalam kriteria yang sama (sedang) dengan takaran $160 \mathrm{~g} /$ pot $(0,29 \%)$. Kadar $\mathrm{N}$ tanah terendah diperoleh pada perlakuan tanpa pemberian kompos yaitu sebesar 0,13\% (kriteria rendah). Ketersediaan $\mathrm{N}$ yang rendah diperkirakan karena proses pelapukan bahan organik yang belum sempurna $(\mathrm{C} / \mathrm{N}$ 
24,19), sehingga sumbangannya ke tanah juga kecil. Namun demikian, sumbangannya ke tanah sudah nampak, tetapi belum maksimal. Menurut Suryadi (1992), N yang berasal dari bahan organik melalui proses mineralisasi akan berubah menjadi $\mathrm{N}$ dalam bentuk tersedia, sehingga dapat meningkatkan $\mathrm{N}$ tanah dan proses itu akan terus berlanjut sampai kompos matang.

Perbandingan nilai $\mathrm{C}$ dan $\mathrm{N}$ pada tanah atau $\mathrm{C} / \mathrm{N}$ tanah sesudah inkubasi tentu sesuai dengan hasil analisis kedua hara tersebut. Dalam mengalami penurunan akibat pemberian kompos. Nilai tersebut secara umum $<20$ tetapi masih dalam kriteria tinggi (Tabel 3).

\section{Kadar P-tersedia Tanah}

Hasil analisis P-tersedia tanah setelah diinkubasi dengan kompos (Tabel 3) masingmasing perlakuan meningkat dengan bertambahnya takaran kompos yang diberikan. Nilai P-tersedia tertinggi terdapat pada perlakuan pemberian kompos $160 \mathrm{~g} /$ pot sebesar 54,58 ppm (kriteria tinggi) sedangkan yang terendah terdapat pada tanpa pemberian kompos yaitu 39,11 ppm (kriteria sedang).

Dari data tersebut, inkubasi tanah dengan kompos mampu meningkatkan kadar P-tersedia tanah. Hal ini dapat disebabkan oleh bahan organik yang mengalami dekomposisi sehingga juga akan meningkatkan asam-asam organik. Asamasam organik tersebut dapat membantu melepaskan P-terjerap sehingga menjadi lebih tersedia. Hal ini, sebelumnya telah dilaporkan oleh Gusnidar (2007) bahwa berbagai jenis asam organik produk antara seperti asam malat, asam sitrat, asam salisilat, dan lainnya dihasilkan dalam proses dekomposisi bahan organik, dan mempengaruhi peningkatan $\mathrm{P}$ tanah sawah. Selain daripada itu, kompos juga menyumbangkan $\mathrm{P}$ pada tanah sawah. Suryadi (1992) berpendapat bahwa peningkatan $\mathrm{pH}$ tanah sawah akibat pemberian kompos, dapat meningkatkan ketersediaan dan kelarutan $\mathrm{P}$ pada tanah sawah, sehingga meningkatkan P-tersedia bagi tanaman. Hal ini terlihat dengan meningkatnya ketersediaan $\mathrm{P}$ sesudah inkubasi pada masing-masing perlakuan dibandingkan dengan tanah sebelum inkubasi. Tingginya P-tersedia juga diakibatkan oleh pemupukan P (TSP atau SP36) secara intensif untuk setiap kali masa tanam dalam jangka waktu yang relatif lama, karena setiap kali panen akan meninggalkan residu $\mathrm{P}$ dalam tanah sawah. Unsur hara $\mathrm{P}$ diambil tanaman hanya sekitar $10-20 \%$, dan selebihnya tertinggal di dalam tanah. Hal ini berlanjut terus setiap musim tanam. Tingginya residu $\mathrm{P}$ dalam tanah sawah di samping disebabkan oleh pemupukan $\mathrm{P}$ dengan dosis yang tinggi, juga disebabkan oleh sifat pupuk $\mathrm{P}$ yang kurang larut dalam air, dan mudah diikat oleh komponen tanah. Dengan penambahan bahan organik seperti kompos kulit jengkol dapat meningkatkan kelarutan $\mathrm{P}$ yang tertimbun dalam tanah. Hasil penelitian Gusnidar (2007), menambahkan bahwa kelarutan $P$ juga dipengaruhi oleh penggenangan, bertambah lama penggenangan $(6-12$ minggu setelah perlakuan), ketersediaan $\mathrm{P}$ semakin meningkat, sehingga peningkatan dosis bahan organik yang diberikan setelah sawah digenangi 12 minggu tidak terlihat pengaruhnya lagi terhadap ketersediaan P.

Nilai Kapasitas Tukar Kation (KTK), Kdd, Ca-dd, dan Mg-dd

Pada Tabel 3, secara umum KTK tanah sesudah inkubasi meningkat dengan meningkatnya takaran kompos yang diberikan. Peningkatan KTK tanah tertinggi terdapat pada perlakuan pemberian kompos $160 \mathrm{~g} /$ pot yaitu sebesar 39,13 me/100g dan berada dalam kriteria yang sama dengan pemberian kompos $80 \mathrm{~g} /$ pot. Tingginya nilai KTK tanah pada perlakuan pemberian kompos $160 \mathrm{~g} /$ pot disebabkan karena bahan organik tanah awal sudah tinggi, dan dosis kompos yang diberikan juga tinggi (setara 40 ton/ha) sehingga mampu menyerap kation yang berada di dalam tanah dalam jumlah yang banyak. Nilai KTK terendah sebesar 11,54 me/100g dengan kriteria rendah terdapat pada perlakuan tanpa pemberian kompos. Dari data ini jelaslah bahwa bahan 
Tabel 3. Beberapa ciri kimia tanah sesudah diinkubasi dengan kompos kulit jengkol selama 3 minggu

\begin{tabular}{|c|c|c|c|c|c|c|c|c|c|c|}
\hline Perlakuan & $\mathrm{pH}$ & N-total ${ }^{*}$ & C-organik & Ratio C/N ${ }^{* *}$ & P-tersedia ${ }^{*}$ & K-dd & Ca-dd* & Mg-dd ${ }^{* *}$ & $\mathrm{KTK}^{*}$ & $\mathrm{Cu}-\mathrm{dd}^{* * * *}$ \\
\hline .....g/pot..... & \multicolumn{4}{|c|}{$\ldots \ldots \ldots \ldots \ldots \ldots \ldots \ldots \ldots \ldots$} & ....ppm..... & \multicolumn{5}{|c|}{ 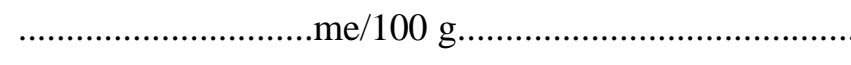 } \\
\hline 0 & $5,73(\mathrm{am})$ & $0,13(r)$ & $2,84(\mathrm{~s})$ & $21,84(\mathrm{t})$ & $39,11(s)$ & $0,73(\mathrm{t})$ & $0,36(\mathrm{sr})$ & $0,60(r)$ & $11,54(r)$ & $18,87(\mathrm{r})$ \\
\hline 20 & $6,03(\mathrm{am})$ & $0,20(r)$ & $3,94(\mathrm{t})$ & $19,70(\mathrm{t})$ & $42,04(\mathrm{t})$ & $1,99(\mathrm{st})$ & $0,47(\mathrm{sr})$ & $0,88(\mathrm{r})$ & 19,19 (s) & $21,86(\mathrm{r})$ \\
\hline 40 & $6,79(n)$ & $0,23(\mathrm{~s})$ & $4,42(\mathrm{t})$ & $19,21(\mathrm{t})$ & $45,60(\mathrm{t})$ & $2,07(\mathrm{st})$ & $0,48(\mathrm{sr})$ & $0,97(r)$ & $24,84(\mathrm{~s})$ & $23,24(r)$ \\
\hline 80 & $6,78(n)$ & $0,29(\mathrm{~s})$ & $4,51(\mathrm{t})$ & $15,55(\mathrm{t})$ & $48,23(\mathrm{t})$ & $2,26(\mathrm{st})$ & $0,59(\mathrm{sr})$ & $1,10(\mathrm{~s})$ & $38,76(\mathrm{t})$ & $25,21(\mathrm{r})$ \\
\hline 160 & $6,82(n)$ & 0,29 (s) & $4,71(\mathrm{t})$ & $16,24(\mathrm{t})$ & $54,58(\mathrm{t})$ & $2,47(\mathrm{st})$ & $0,84(\mathrm{sr})$ & $1,14(s)$ & $39,13(t)$ & $27,97(\mathrm{r})$ \\
\hline
\end{tabular}

Keterangan : am = agak masam, $\mathrm{m}=$ masam, $\mathrm{n}=$ netral, $\mathrm{sr}=$ sangat rendah, $\mathrm{r}=$ rendah, $\mathrm{s}=$ sedang, $\mathrm{t}=$ tinggi, $\mathrm{st}=$ sangat tinggi Sumber kriteria :

\footnotetext{
*) : Staf Pusat penelitian tanah (1983; cit Hardjowigeno, 2003)

**) : Team 4 Architects and Consulting Engineer bekerjasama dengan Fakultas Pertanian Universitas Andalas (1981)

***) : Rosmarkan dan Yuwono (2002).
} 
organik berupa kompos dapat menaikkan nilai KTK tanah, sehingga kemampuan tanah untuk menahan hara diharapkan juga akan lebih baik.

Dengan pemberian kompos sebagai bahan organik ke dalam tanah sangat berpengaruh terhadap kesuburan tanah. Bahan organik mempunyai daya jerap yang lebih besar dari pada koloid liat. Berarti semakin tinggi kandungan bahan organik suatu tanah makin tinggi pula KTKnya (Hakim et al, 1986). Suryadi (1992) menambahkan bahwa peningkatan KTK tanah akibat pemberian kompos diduga karena meningkatnya muatan negatif dalam tanah, muatan negatif berasal dari gugus karboksil $\left(\mathrm{COO}^{-}\right)$dan hidroksil $\left(\mathrm{OH}^{-}\right)$yang dikandung kompos.

Begitu juga dengan nilai K-dd tanah sesudah perlakuan, pada masing-masing perlakuan meningkat dengan meningkatnya takaran kompos yang diberikan. Peningkatan terbesar diperoleh pada pemberian kompos $160 \mathrm{~g} /$ pot yaitu sebanyak 2,47 me/100g dengan kriteria sangat tinggi dan terendah terdapat pada perlakuan tanpa pemberian kompos yaitu $0,73 \mathrm{me} / 100 \mathrm{~g}$ dengan kriteria tinggi. Hal ini menunjukkan bahwa penambahan kompos kulit jengkol ke lahan dapat meningkatkan ketersediaan $\mathrm{K}$ sehingga menjadi tersedia bagi tanaman. Di samping sebagai sumber bahan organik yang tinggi kadar K nya (Tabel 3), pemberian kompos juga dapat melarutkan unsur $\mathrm{K}$ yang terjerap dalam tanah, yang sebelumnya kurang tersedia menjadi tersedia bagi tanaman.

Nilai Ca-dd, sesudah inkubasi kompos juga mengalami peningkatan dibanding dengan sebelum inkubasi, tetapi masih pada kriteria sangat rendah. Nilai Cadd tertinggi terdapat pada perlakuan pemberian kompos $160 \mathrm{~g} /$ pot yaitu sebanyak $0,84 \mathrm{me} / 100 \mathrm{~g}$ (kriteria sangat rendah), dan terendah terdapat pada perlakuan tanpa kompos yaitu 0,36 me/100g (kriteria sangat rendah). Berarti dengan penambah kompos kulit jengkol pada tanah sawah ternyata juga memberikan pengaruh terhadap Ca-dd dalam tanah meskipun hanya sedikit. Sangat rendahnya kadar Ca-dd tanah, baik sebelum maupun sesudah diberi kompos, mengindikasikan bahwa kadar Ca-dd tanah sawah sudah harus mendapat perhatian serius, terutama pada tanah-tanah sawah yang dikelola secara intensif. Hal yang sama sebelumnya juga telah dilaporkan oleh Gusnidar et al (2008) untuk tanah sawah yang dikelola secara intensif dua kali setahun di Sicincin Kecamatan 2x11 Enam Lingkung Kabupaten Padang Pariaman. Keadaan ini dapat disebabkan oleh pemupukan hanya terfokus pada pemberian $\mathrm{N}$, dan $\mathrm{P}$ secara umum, dan agak jarang penggunaan pupuk $\mathrm{K}$. Walaupun unsur $\mathrm{Ca}$ menjadi unsur ikutan pada pupuk TSP ataupun SP-36, namun belum mencukupi kebutuhan tanaman. Unsur ini terus terkuras setiap musim tanam, akibatnya ketersediaannya menjadi berkurang.

Begitu juga dengan Mg-dd, dengan meningkatnya takaran kompos yang diberikan juga dapat meningkatkan nilai $\mathrm{Mg}$ dd walaupun sedikit. Kompos kulit jengkol memberikan sumbangan Mg-dd tertinggi terdapat pada perlakuan pemberian kompos $160 \mathrm{~g} /$ pot yaitu sebesar $1,14 \mathrm{me} / 100 \mathrm{~g}$ yang termasuk kriteria sedang, dan berada dalam kriteria yang sama akibat pemberian kompos 80 g/pot. Kadar Mg-dd terendah terdapat pada perlakuan tanpa kompos yaitu 0,60 me/100 g (kriteria rendah), dan berada dalam kriteria yang sama akibat pemberian kompos kulit jengkol sebanyak $20-40$ g/pot. Pola kenaikan kriteria $\mathrm{Mg}$-dd ini, seirama dengan kenaikkan nilai KTK tanah. Sebagaimana unsur $\mathrm{Ca}, \mathrm{Mg}$ juga jarang diberikan berupa pupuk oleh petani ke lahan, akibatnya unsur $\mathrm{Mg}$ juga terus terkuras setiap musim tanam. Berdasarkan temuan ini, maka pada lahanlahan sawah yang dikelola secara intensif sudah harus diberi pupuk mengandung $\mathrm{Ca}$ maupun $\mathrm{Mg}$, atau perlu diberi kapur dolomit sebagai input pupuk ke lahan. Berapakah dosis yang tepat dolomit itu harus diberikan, tentu perlu juga dikaji melalui suatu penelitian.

Kadar $\mathrm{Cu}-\mathrm{dd}$ tanah

Secara umum kadar $\mathrm{Cu}$-dd tanah rendah (Tabel 3), cukup, dengan kadar $\mathrm{Cu}$ terendah terdapat pada perlakuan tanpa kompos yaitu 18,87 ppm (kriteria rendah) 
dan $\mathrm{Cu}$ tertinggi terdapat pada pemberian kompos 160 g/pot yaitu sebeesar 27,97 ppm (kriteria rendah). Kadar $\mathrm{Cu}$ dalam tanah sering berlawanan dengan kadar P-tanah. Semakin intensifnya pemupukan $\mathrm{P}$, maka secara umum kadar $\mathrm{Cu}$ tanah menurun. Unsur ini termasuk unsur mikro essensial dan perlu juga diperhatikan tigkat ketersediaannya dalam jumlah yang cukup bagi tanaman, akan tetapi tidak meracun tanaman.

Pertumbuhan tanaman

Tnggi tanaman (Tabel 4) relatif sama, berarti belum ada pengaruh kompos terhadap tinggi tanaman. Namun pada Gambar 1, dari grafik perkembangan tinggi tanaman, nampaknya pengaruh takaran kompos itu ada, namun belum nyata secara statistik. Hal ini diperjelas oleh data jumlah anakan produktif. Pemberian kompos $20 \mathrm{~g} /$ pot belum ada pengaruhnya terhadap jumlah anakan produktif. Peningkatan pemberian kompos menjadi 40 - $160 \mathrm{~g} /$ pot, dapat meningkatkan jumlah anakan produktif akan tetapi pengaruhnya relatif sama pada takaran 40, 80 dan $160 \mathrm{~g} /$ pot. Jumlah anakan produktif akibat peningkatan takaran kompos seiring dengan meningkatnya kadar hara seperti N, P, $\mathrm{K}, \mathrm{Mg}$ dan Ca dalam tanah. Di samping itu, pemberian kompos kulit jengkol sebagai bahan organik dapat meningkatkan daya pegang tanah terhadap air, sehingga tanaman mempunyai cukup air dan oksigen

Tabel 4. Pengaruh pemberian kompos terhadap tinggi tanaman, jumlah anakan total dan jumlah anakan produktif padi sawah

\begin{tabular}{|c|c|c|c|}
\hline Takaran kompos & Tinggi tanaman & $\begin{array}{c}\text { Jumlah anakan } \\
\text { total }\end{array}$ & $\begin{array}{c}\text { Jumlah anakan } \\
\text { produktif }\end{array}$ \\
\hline …......g/pot.......... & ..........cm........... & \multicolumn{2}{|c|}{ ….....................batang/rumpun...................... } \\
\hline 0 & 105,66 & 24,66 & 20,00 \\
\hline 20 & 109,66 & 25,00 & $21,00 \mathrm{bc}$ \\
\hline 40 & 111,33 & 25,00 & $22,33 \mathrm{ab}$ \\
\hline 80 & 112,00 & 27,00 & $24,00 \mathrm{a}$ \\
\hline 160 & 111,66 & 26,00 & $24,00 \mathrm{a}$ \\
\hline KK & $2,91 \%$ & $8,82 \%$ & $5,05 \%$ \\
\hline
\end{tabular}

untuk respirasinya. Akibatnya pertumbuhan tanaman semakin baik. Sedangkan jumlah anakan total antar perlakuan juga relatif sama. Jika dibandingkan dengan deskripsi yang dikeluarkan oleh BPTP Sumatera Barat, tinggi tanaman berkisar antara 90 sampai 105 $\mathrm{cm}$. Dalam penelitian ini diperoleh tinggi tanaman melebihi angka tersebut. Hal ini dapat disebabkan oleh tingginya suhu rumah kaca tempat penelitian dan perbedaan takaran kompos yang diberikan.

Bobot Jerami, Bobot Gabah dan Bobot 1000 Biji

Peningkatan takaran kompos tidak memperlihatkan perbedaan yang nyata terhadap bobot jerami dan bobot 1000 biji. namun nyata terhadap bobot gabah (Tabel $5)$.

Pengaruh peningkatan takaran kompos masih relatif sama terhadap perolehan jerami dan bobot 1000 biji tiap pot. Dari data bobot 1000 biji yang didapatkan, mengindikasikan bahwa hara yang diberikan dalam percobaan ini belum mendukung kualitas gabah yang lebih baik. Berat 1000 biji yang diperoleh masih jauh dari hasil deskripsi tanaman varitas Ir 42 yaitu seberat $21,4-23,3$ g. Hal ini menunjukkan bahwa masih diperlukan variasi pemberian hara lain agar pertumbuhan dan bobot 1000 biji supaya lebih meningkat. 
Keterangan : Angka-angka dalam kolom yang sama yang diikuti oleh huruf kecil yang sama adalah berbeda tidak nyata menurut uji DNMRT taraf $5 \%$.

Tabel 5. Pengaruh pemberian kompos kulit jengkol terhadap bobot jerami, bobot gabah dan bobot 1000 biji (g/pot) padi

\begin{tabular}{|c|c|c|c|}
\hline Takaran kompos & Bobot jerami & Bobot gabah & bobot 1000 biji \\
\hline .........g/pot......... & \multicolumn{3}{|c|}{ 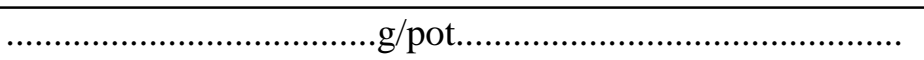 } \\
\hline 0 & 37,95 & $21,13 \mathrm{~b}$ & 13,40 \\
\hline 20 & 39,73 & $21,51 \mathrm{~b}$ & 13,89 \\
\hline 40 & 39,82 & $22,36 \mathrm{ab}$ & 14,15 \\
\hline 80 & 40,93 & $23,93 \mathrm{a}$ & 14,23 \\
\hline 160 & 40,32 & 23,81 a & 14,19 \\
\hline KK & $3,62 \%$ & $4,33 \%$ & $4,05 \%$ \\
\hline
\end{tabular}

Keterangan: Angka-angka dalam kolom yang sama yang diikuti oleh huruf kecil yang sama adalah berbeda tidak nyata menurut uji DNMRT taraf $5 \%$

Tabel 6. Pengaruh pemberian kompos terhadap serapan hara N, P, dan K tanaman

\begin{tabular}{|c|c|c|}
\hline \multirow{2}{*}{ Perlakuan } & \multicolumn{2}{|c|}{ Serapan hara } \\
\hline & Jerami & Gabah \\
\hline$\ldots . .(\mathrm{g} / \mathrm{pot}) \ldots . .$. & \multicolumn{2}{|c|}{ 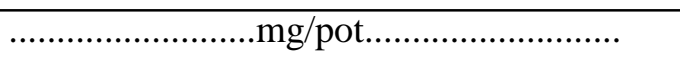 } \\
\hline \multicolumn{3}{|l|}{ Serapan N } \\
\hline 0 & 4,02 & 11,80 \\
\hline 20 & 4,13 & 13,07 \\
\hline 40 & 4,82 & 12,80 \\
\hline 80 & 4,12 & 14,10 \\
\hline 160 & 4,94 & 12,86 \\
\hline $\mathrm{KK}$ & $12,15 \%$ & $17,58 \%$ \\
\hline \multicolumn{3}{|l|}{ Serapan P } \\
\hline 0 & 3,03 & 10,95 \\
\hline 20 & 3,57 & 11,24 \\
\hline 40 & 3,76 & 11,97 \\
\hline 80 & 3,82 & 12,12 \\
\hline 160 & 3,43 & 10,90 \\
\hline $\mathrm{KK}$ & $11,55 \%$ & $10,13 \%$ \\
\hline \multicolumn{3}{|l|}{ Serapan K } \\
\hline $\begin{array}{ll}1 & 0\end{array}$ & $35,78 \mathrm{~b}$ & 16,97 \\
\hline 20 & $38,27 \mathrm{ab}$ & 18,53 \\
\hline 40 & $40,13 \mathrm{a}$ & 21,69 \\
\hline 80 & $41,16 \mathrm{a}$ & 18,61 \\
\hline 160 & $39,68 \mathrm{ab}$ & 16,05 \\
\hline KK & $5,56 \%$ & $24,76 \%$ \\
\hline
\end{tabular}




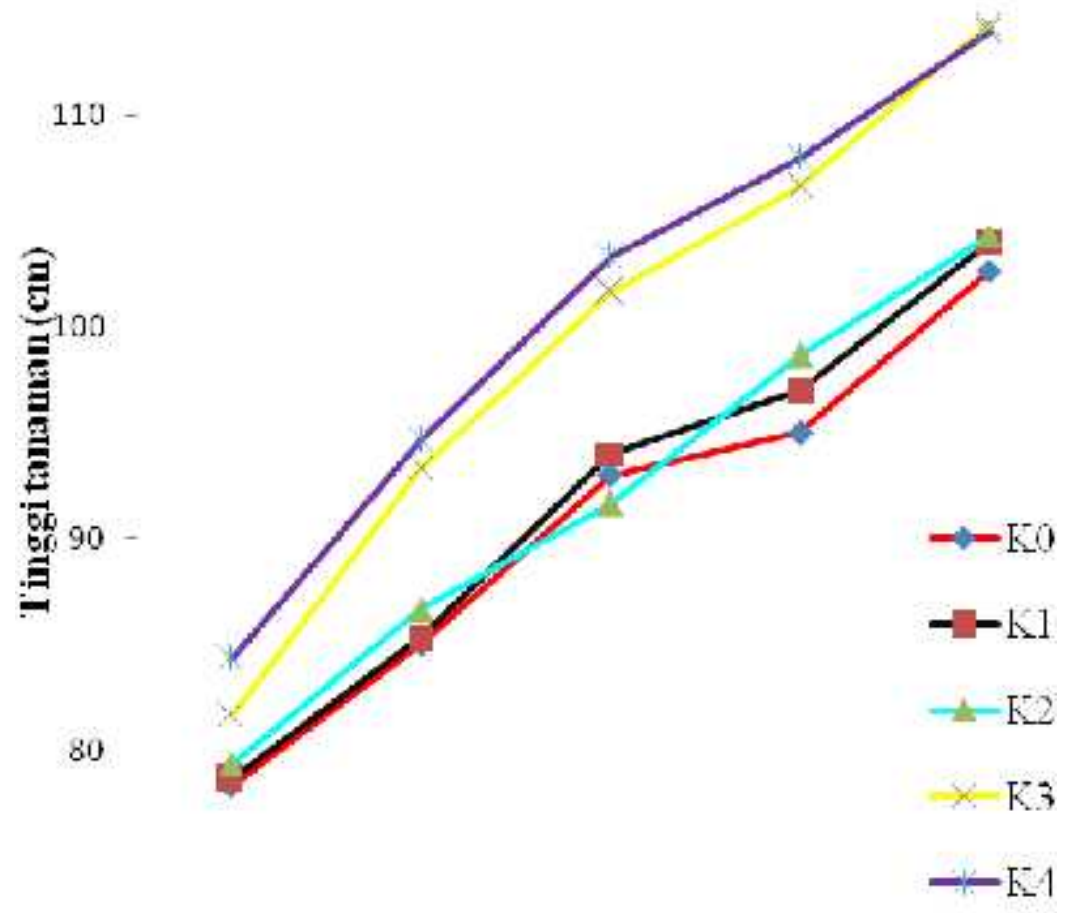

70

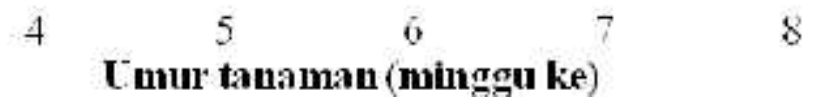

Gambar 1. Grafik pertumbuhan tinggi tanaman pada berbagai perlakuan kompos

Peningkatan takaran kompos dari $80 \mathrm{~g} / \mathrm{pot}$ ke $160 \mathrm{~g} /$ pot tidak mempengaruhi berat gabah, sehingga takaran $80 \mathrm{~g} /$ pot sudah cukup untuk berat gabah tertinggi. Hal ini berbeda dengan hasil analisis tanah setelah inkubasi bahkan ketersediaan hara yang baik terdapat pada perlakuan pemberian kompos $160 \mathrm{~g} /$ pot. Fenomena ini juga memberi petunjuk bahwa komposisi hara yang diberikan belum mampu mendukung pertumbuhan dan produksi yang lebih baik. Apalagi asal tanah yang digunakan adalah Ultisol yang tidak selalu disawahkan selama 12 tahun terakhir. Keadaan ini dapat menyebabkan sifat-sifat Ultisol yang tidak mendukung pertumbuhan tanaman seperti kelarutan ion ferro yang tinggi waktu digenangi, dan kelarutan ion ferri yang meracun pada saat dikeringkan terjadi. Namun dalam penelitian ini tidak dilakukan analisis hara tersebut. Akan tetapi, dibanding pertmbuhan dan hasil padi pada Ultisol yang baru ddisawahkan, hasil yang diperoleh dalam penelitian ini sudah lebih baik.

Serapan Hara N, P, dan K Tanaman

Peningkatan takaran kompos sampai 160 g/pot terhadap serapan $\mathrm{N}$ jerami dan $\mathrm{N}$ gabah, serta serapan $\mathrm{P}$ jerami dan $\mathrm{P}$ gabah berbeda tidak nyata (Tabel 6). Begitu juga terhadap serapan $\mathrm{K}$ gabah masih berbeda tidak nyata. Peningkatan takaran kompos hanya nyata terhadap serapan $\mathrm{K}$ jerami. 
Serapan K jerami tertinggi diperoleh pada pemberian $80 \mathrm{~g}$ kompos kulit jengkol $(41,16 \mathrm{~g} /$ pot $)$ yang berbeda tidak nyata dengan input kompos $20 \mathrm{~g}, 40 \mathrm{~g}$ dan $80 \mathrm{~g} /$ pot. Nampaknya pemberian kompos $40 \mathrm{~g} /$ pot telah cukup untuk memperoleh serapan $\mathrm{K}$ jerami yang lebih baik, namun besar butir akan lebih baik jika takaran kompos $80 \mathrm{~g} /$ pot. Hal ini juga dipengaruhi oleh unsur hara terutama $\mathrm{N}, \mathrm{P}$ dan $\mathrm{K}$ yang tersedia dalam tanah. Dari hasil analisis N, $\mathrm{P}$, dan $\mathrm{K}$ jerami dan gabah pemberian kompos $80 \mathrm{~g} /$ pot sudah cukup untuk kebutuhan serapan hara tanaman padi.

Dari keseluruhan parameter tanaman yang diamati (Tabel 4,5 dan 6) serta didukung oleh hasil analisis tanah setelah inkubasi, maka takaran kompos $80 \mathrm{~g} /$ pot (setara 20 ton/ha) sudah cukup untuk mendukung pertumbuhan dan produksi yang tinggi dalam penelitian ini.

\section{KESIMPULAN}

Berdasarkan hasil penelitian yang telah dikemukakan, maka diperoleh kesimpulan sebagai berikut:

1. Pemberian kompos kulit jengkol sebanyak $80 \mathrm{~g} /$ pot merupakan perlakuan terbaik dengan bobot gabah sebanyak $23,93 \mathrm{~g} /$ pot, bobot 1000 biji sebesar 14,23 g/pot, dan serapan K jerami diperoleh 41,16 g/pot.

2. Pemberian kompos kulit jengkol pada tanah sawah mampu memperbaiki sifat kimia tanah. Hasil terbaik diperoleh pada pemberian kompos 160 g/pot terhadap $\mathrm{pH} \mathrm{H}_{2} \mathrm{O}$ (meningkat dari 5,60 menjadi 6,82); N-total (meningkat dari $0,13 \%$ menjadi 0,29\%); C-organik (meningkat dari 2,84\% menjadi 4,71\%); kadar Ptersedia (meningkat dari 39,11 ppm menjadi $54.58 \mathrm{ppm}$ ); kadar K-dd (meningkat dari 0,73 me/100g menjadi 2,47 me/100g); kadar Cadd (meningkat dari 0,36 me/100g menjadi 0,84 me/100g); kadar $\mathrm{Mg}$ dd (meningkat dari 0,60 me/100g menjadi $1,14 \mathrm{me} / 100 \mathrm{~g}$ ); nilai KTKtotal juga bertambah dari 11,54 me/100g menjadi 39,13 me/100g.

\section{DAFTAR PUSTAKA}

Delsi, Y. 2010. Viabilitas dan Vigor Gulma yang diberi Beberapa Konsentrasi Ekstrak Kulit Jengkol dan Pengaruhnya Terhadap Tanaman Padi. Skripsi S1. Fakultas MIPA Universitas Andalas. Padang. 108 hal.

Enni, S.R. dan Krispinus K.P. 1998. Kandungan Senyawa Kimia Kulit Buah Jengkol (Pithecelobium lobatum Benth) dan Pengaruh terhadap Pertumbuhan Beberapa Gulma Padi. Laporan penelitian, Lembaga Penelitian IKW Semarang. 12 hal.

Gusnidar. 2007. Budidaya dan pemanfaatan Tithonia diversifolia untuk menghemat

pemupukan $\mathrm{N}, \mathrm{P}$, dan $\mathrm{K}$ padi sawah intensifikasi. Disertasi Doktor. Program Pascasarjana, Universitas Andalas Padang. 256 hal.

Gusnidar, S. Yasin, dan Burbey. 2008. Pemanfatan gulma Tithonia diversifolia dan jerami sebagai bahan organik in situ untuk mengurangi penggunaan pupuk buatan serta meningkatkan hasil padi sawah intensifikasi. Laporan hasil penelitian KKP3T. Kerjasama Unand-Litbang Pertanian. Padang. 49 hal.

Hakim, N., M. Y. Nyakpa., A. M. Lubis., G. Nugroho., M. A. Saul., M. Diha., G. B. Hong, dan H. H. Bailey. 1986. Dasar-dassar Ilmu Tanah. Penerbit Universitas Lampung. Bandar lampung. 488 hal.

Herviyanti. 2007. Pengendalian keracunan besi dengan asam humat dan pengelolaan air untuk meningkatkan produktivitas Ultisol yang baru disawahkan. Disertasi Doktor. Program Pascasarjana, Universitas Andalas. Padang. 179 hal.

Pitojo, S. 1995. Jengkol Budidaya dan Pemanfaatannya. Kanisius. 72 hal.
Yogyakarta; 
Rykson, S., dan Sudadi, U. 2001. Tanah Sawah (Bahan Kuliah). Institut Pertanian Bogor (IPB). Bogor. 105 hal.
Suryadi, 1992. Pengaruh pemberian kompos dan pupuk TSP terhadap ketersediaan fosfat dan produksi padi sawah (Skripsi). Fakultas Pertanian Universitas Andalas. Padang. 54 hal 